\title{
The Lack of English teachers' Intercultural Communicative Competence
}

\section{and the Promotion Strategies}

\author{
Qiaohong Zhao ${ }^{1, \text { a }}$ \\ ${ }^{1}$ Luohe Medical College, Luohe City, Henan Province, China, 462000 \\ a email:
}

Keywords: English Teachers, Intercultural Communicative Competence, College English Teaching, Quality of Teachers, Educational Reform

\begin{abstract}
There is a certain gap between the intercultural communication competence of foreign language teachers in China's universities and the business needs and the social expectation. Based on the author's teaching experiences, this paper first analyzes the lack of English teachers' intercultural communicative competence, and then puts forward targeted promotion strategies. The promotion of intercultural communicative competence of foreign language teachers in colleges and universities is related to the cultivation of international talents and the promotion of the competitiveness of colleges and universities, which should receive the common attention of all aspects.
\end{abstract}

\section{Introduction}

Students' intercultural communicative competence is mainly from the teachers' teaching, and a great teacher produces a brilliant student. The improve of the intercultural communicative competence of foreign language teachers in Colleges and universities is becoming more and more urgent and important. Limited by a number of factors, there is still a certain gap between the intercultural communication competence of foreign language teachers in China's universities and the business needs and the social expectation. It is necessary for colleges and university foreign language teachers to explore and practice how to improve the intercultural communicative competence of college foreign language teachers effectively and rapidly from the reality

\section{The Lack of English Teachers' Intercultural Communicative Competence}

The lack of awareness of intercultural communicative competence. Many teachers think that the strong language ability of a foreign language teacher is the most important condition. Being good at speaking, writing and translating is having the first quality of intercultural communication. The main problem with teachers holding this kind of knowledge is that they think the knowledge of language and the knowledge of intercultural communication competence are equivalent. Intercultural communicative competence is a comprehensive ability of language communicative competence, nonverbal communicative competence, intercultural understanding competence, linguistic rules, the ability of communicative rules transformation and the ability of cross-cultural adaptation. Vocabulary, syntax and other linguistic knowledge are only a part of language communicative competence, which is the basis of communicative competence. The language ability of foreign language teachers is indeed very important, but the development of this ability is also 
influenced by the social and cultural elements all the time. Because language is an important part of the spiritual and social relations of a nation and culture, it is a witness of the historical development of culture. Foreign language teachers must be clearly aware that the language ability does not mean that it can successfully communicate, without a certain level of cultural competence and communicative competence, intercultural communicative competence can not be improved in essence. Language is the carrier of culture, we can see cultural norms and customs of people in different cultures through the language. Language and culture are inseparable, learning a foreign language must learn culture, foreign language teaching must be combined with culture teaching. The pure language ability which is separated from the culture is just a kind of virtual ability which is used in the real context.

The lack of cross cultural communication skills training. Because of the shortage of foreign language teachers and the heavy teaching task, there are not many opportunities and time for teachers to take part in job training, no to mention the training of teachers' culture teaching and intercultural communicative competence. Although the number of teachers with doctoral degree has been greatly increased, the teachers who have not received any training in teaching are still not in the minority. In fact, in recent years, some colleges and universities have actively held some training courses to improve foreign language teachers' intercultural communicative competence. For example, "research center of Chinese foreign language teaching materials and teaching methods" in Shanghai International Studies University holds training classes on language and culture, cross cultural communication and other aspects for English teachers in colleges and universities almost every year.

The lack of opportunity to experience foreign cultures. Due to the limit of political and economic, geographical environment, many foreign language teachers lack cross-cultural perspective and do not have the ability to apperceive, understand and abandon the traditional Chinese and western culture. Although teaching foreign languages, they lack real experience of foreign languages and have to teach students language and cultural knowledge through book knowledge. Ideal state of foreign language teachers is to study or live abroad for at least one year, and have a certain degree experiences of cross cultural communication. Short term travel abroad can not make cross-cultural communication ability really improve, using the cross-cultural perspective formed in a short period of time to guide students to improve cross-cultural communication skills will also be misleading.

The lack of knowledge structure of cross cultural communication. Different learning control is an important part of the knowledge structure of intercultural communication competence. At the same time, we should understand the culture shock, culture shock, cultural adaptation, cultural adjustment and other problems appeared in the practice of intercultural communication and experience processes, understanding these can enrich the knowledge structures of foreign language teachers. Because of the high pressure of society, family and work, many foreign language teachers are busy with part-time teaching and write research papers, and ignore their own self-cultivation gradually. Slack and culture accumulation is not enough to result in teaching often to kick the tires on the introduction of culture in foreign language teaching, cannot expand the breadth and depth and explore. The result of slackness and not enough culture accumulation is that teachers usually introduce a little culture in foreign language teaching, and cannot expand and explore the breadth and depth .

The lack of the new teaching concept of cross-cultural communication. Most teachers know the importance of the cultivation of intercultural communication competence and the necessity of culture introduction in teaching, but they lack the concept of cross cultural communication teaching 
and still use the traditional teaching mode and teaching methods for teaching. Some teachers just read according to relevant cultural aspects materials and do not discuss contents, the classroom effect is not satisfactory. Some teachers explain and read according to cultural communication teaching materials, and then do some choice questions, lack students actively participated in classroom communication activities, and there is of little help for students to improve their intercultural communicative competence. Students feel that there is just for a change of teaching materials, teaching forms and content does not seem to change. The teaching method of "changing the liquid but not the drugs" make it difficult for the students to have the ability to expand the breadth and depth of the cross cultural communication. Language, culture and communication have been artificially divided in teaching.

\section{The Improving Strategies of English Teachers' Intercultural Communicative Competence}

Promoting high teachers' awareness of intercultural communicative competence. General lectures and articles emphasize the need to improve students' understanding of intercultural communicative competence. In fact, the first step should be improving the teacher's understanding of intercultural communicative competence. Foreign language teachers are the key to realize the goal of the reform of foreign language teaching and the cultivation of students' intercultural communicative competence. The appearance of teachers' concept and ability is closely related to the cultivation of students' intercultural communicative competence. Teachers must be aware that learning a foreign language is not for the sake of the test, just knowing the literal meaning of the word is far from enough, they must also know how to use it and when to use it, they also need to understand the rules and constraints in the actual communication. Otherwise, it will cause misunderstandings in intercultural communication.

Normalized training of cross cultural communication skills. Paying attention to training of intercultural communicative competence of foreign language teachers, and making them have a better understanding of the theory of intercultural communication, master the intercultural communication of the main activities, have a higher cross cultural communicative competence, so that they can shoulder the task of cultivating students' intercultural communicative competence. Schools having good conditions can implement systematic, standardized and normalized training to promote the change of concept and professional development of foreign language teachers. In the interactive dialogue, let the teachers understand themselves, enhance the concept, discuss and solve the problems of intercultural communicative competence appeared in the teaching and practice process. Training can be carried out and guided by the cross cultural communication experts. Or we can invite teachers who have a long time study abroad experiences to talk about cultural differences and cultural understanding, and exchange their own experiences. Training should be: theory links to practice, personal experience links to expert analysis, the teacher's theoretical knowledge links to cultural accumulation and cross-cultural communication theory.

Finding more channels to understand, experience and absorb foreign culture. The understanding, experience and absorption of foreign culture is very important to improve of the quality of intercultural competence of foreign language teachers themselves. They should use a variety of channels and means to absorb and experience the exotic culture. One is to understand the foreign geography, history, art, local customs and practices through reading. Two is to use English movies, television, new media and other information. Increasing their indirect intuitive experience when giving students the indirect, intuitive feelings, and sharing same cultural experience space and dimension with students. Since indirect context may be the real context, teachers can make full use of indirect context to expand cultural knowledge in the absence of the target language to provide 
direct context experience. Three is to use foreign teachers resources to communicate, understand the meaning of intercultural communicative competence in the real language environment. Four is to use the advantage of Internet information integration to expand a certain cultural point or surface to generate a sense of space and time dimension, and deepen the level of cognition.

Adding the absent knowledge structure of cross intercultural communication. In twenty-first Century, the requirements of foreign language teachers are not only have a good knowledge of language, but also have a more complete knowledge structure of cross cultural communication. The knowledge structure is composed of at least three parts: knowledge of culture, knowledge of language and knowledge in communication. The cultural level of knowledge covers a wide range, because culture is the total human progress model of a society with the unique beliefs, habits, systems and so on, history, geography, literature, religion, sociology and other knowledge can be returned at the cultural level. The more understanding of the knowledge, the better, not only the foreign culture, but also the culture of the nation. Linguistic knowledge should include not only the knowledge of the language itself, the vocabulary and grammar knowledge, but also include a wealth of knowledge about the name nationality traditional culture and the knowledge of the essential features of human language and the law of special use.

Renewing the teaching concept of cross cultural communication, improving teaching methods. Foreign language teachers should pay attention renew the concept of intercultural communication teaching, reflect in the cross cultural communication teaching and relocation the role of teachers. We should recognize that learning a foreign language is to communicate, and communication needs the support of culture. The culture is diverse and dynamic. Foreign language teachers should shift from the teaching person to the initiator, the navigator and the training person. In the course of teaching, they should train themselves and students to be a multicultural person who can successfully communicate in a global environment. In the teaching of cultivating students' ability to realize cross cultural communication, foreign language teachers should become a bridge for communicating students individual culture and the culture of the target language, become the initiator of cultural knowledge, the navigator of cultivating intercultural communicative awareness, the training person of improving cross cultural strategies.

\section{Conclusion}

The fundamental purpose of foreign language teaching is to achieve cross-cultural communication, that is, making students communicate effectively cross cultural with people of different cultural backgrounds. One of the goals of English curriculum teaching in English schools is the ability of cross cultural understanding. Bairam, a famous British scholar, pointed out that, foreign language teaching is the expansion of the national education and the cultivation of cross cultural citizens. Intercultural Citizenship is not a problem of identification but a problem of ability: skill, attitude, knowledge, and action. To cultivate students' cultural awareness and intercultural communicative competence, teachers must have their own skills, otherwise it is difficult for students to improve their intercultural communicative competence. Foreign language education in colleges and universities shoulder the historical mission of understanding the world, inheriting civilization, educating people, servicing society, the quality of foreign language teachers and their intercultural communicative competence play a decisive role in the completion of the above mission.

\section{References}


[1] Hu Wenzhong. How to locate the foreign language circle in the foreign language teaching [J]. 2013,06:2-8.

[2] Wang Na. An Empirical Study on the cultivation of intercultural communicative competence of foreign language teachers [D]. Guangxi University, 2005

[3] Hou Ruijun. The cultivation of intercultural communicative competence of foreign language teachers in Colleges and universities [J]. Heilongjiang high education research, 2003,06:74-75.

[4] Gui Fenglan. Cross cultural communicative competence of foreign language teachers in Colleges and Universities and the path of ascension [J].Higher agricultural education, 2015,12:54-56.

[5] Zhou Jie. A study on intercultural communicative competence of College English teachers [D]. Yanshan University, 2009. 